\title{
Hubungan Pengetahuan dan Sikap Ibu dengan Upaya Pencegahan Stunting pada Balita di Wilayah Kerja Puskesmas Simpang Kawat Kota Jambi
}

\author{
Sri Arnita ${ }^{1}$, Dwi Yunita Rahmadhani ${ }^{2}$, Mila Triana Sari ${ }^{3}$ \\ ${ }^{1}$ Prodi SI Keperawatan STIKes Baiturrahim Jambi \\ ${ }^{2,3}$ Prodi SI Keperawatan STIKes Baiturrahim Jambi \\ Email: sriarnita53@gmail.com
}

Submitted : 25/09/2019

Accepted: 06/02/2020

Published: $14 / 03 / 2020$

\begin{abstract}
Stunting is a condition in which an toddler has a length and heights are less when compared with age caused by multidimensional factors, namely poor nutritional factors experienced by toddlers, lack of maternal knowledge about health and nutrition, impact on the level of intelligence, susceptibility to disease. This study aimed to determine the correlation of knowledge and mother's attitude with stunting prevention efforts in toddlers. This is quantitative research by using cross sectional design; it was conducted at the public health center Simpang Kawat Jambi city from February until July 2019. Populations were 881 people with total samples were 87 mother. The sample used proportional random sampling, analyzed as univariate and bivariate by using chisquare test. The findings indicated that from 87 mother, most of the mother (67.8\%) have good stunting prevention efforts, most of the mother (65.5\%) have high knowledge, most of the mother (64.4\%) have good attitude. The result of this study were obtained there is significant correlation between knowledge with stunting prevention efforts in infants where $p$-value $=0.373(p>0.05)$. There is significant correlation between attitude with stunting prevention efforts in toddlers where $p$-value $=0.030$ ( $p<0.05)$. It is expected to the public health center Simpang Kawat to stunting prevention efforts carried out primary prevention through health promotion in providing understanding about stunting so that a change of attitude which is expected in achieve optimal health.
\end{abstract}

Keywords: attitude, knowledge, prevention efforts, stunting, toddlers

\begin{abstract}
Abstrak
Stunting (kerdil) adalah kondisi dimana balita memiliki panjang dan tinggi badan yang kurang jika dibandingkan dengan umur disebabkan oleh faktor multidimensi yaitu faktor gizi yang buruk yang dialami balita, kekurangan pengetahuan ibu tentang kesehatan dan gizi, berdampak pada tingkat kecerdasan, kerentanan terhadap penyakit. Penelitian ini bertujuan untuk mengetahui hubungan pengetahuan dan sikap ibu dengan upaya pencegahan stunting pada balita. Penelitian ini merupakan penelitian Kuantitatif dengan desain Cross Sectional yang dilakukan di Wilayah Kerja Puskesmas Simpang Kawat Kota Jambi dari Februari sampai Juli tahun 2019. Populasi dalam penelitian ini berjumlah 881 orang dengan jumlah sampel 87 Ibu. Teknik pengambilan sampel dengan Proporsional Random Sampling, dianalisis secara univariat dan bivariat dengan menggunakan uji chi-square. Hasil analisis penelitian diketahui dari $87 \mathrm{Ibu}$, sebagian besar Ibu $(67.8 \%)$ memiliki upaya pencegahan stunting yang baik, sebagian besar Ibu (65.5\%) memiliki pengetahuan tinggi, sebagian besar Ibu (64.4\%) memiliki sikap baik, tidak ada hubungan yang bermakna antara pengetahuan dengan upaya pencegahan stunting pada balita dimana $p$-value = 0.373 ( $\mathrm{p}>0.05$ ), ada hubungan yang bermakna antara sikap dengan upaya pencegahan stunting pada balita dimana $p$-value $=0.030(\mathrm{p}<0.05)$. Diharapkan bagi Puskesmas Simpang Kawat untuk upaya pencegahan stunting dilakukan pencegahan primer melalui promosi kesehatan dalam memberikan pemahaman tentang stunting sehingga terjadi perubahan sikap yang diharapkan dalam mencapai tingkat kesehatan yang optimal.
\end{abstract}

Kata kunci : balita, pengetahuan; sikap; stunting, upaya pencegahan 


\section{PENDAHULUAN}

Salah satu target Sustainable Development Goals (SDGs) yang termasuk pada tujuan pembangunan berkelanjutan ke2 yaitu menghilangkan kelaparan dan segala bentuk malnutrisi pada tahun 2030 serta mencapai ketahanan pangan. Target yang ditetapkan adalah menurunkan angka stunting hingga $40 \%$ pada tahun 2025. Untuk mewujudkan hal tersebut pemerintah menetapkan stunting sebagai salah satu program prioritas. Berdasarkan Peraturan Menteri Kesehatan Nomor 39 Tahun 2016 tentang Pedoman Penyelenggara Program Indonesia Sehat dengan Pendekatan Keluarga (Kemenkes RI, 2018).

Stunting atau pendek didefinisikan sebagai kondisi gagal tumbuh pada bayi (011 bulan) dan anak balita (12-59 bulan) akibat dari kekurangan gizi kronis terutama dalam 1.000 hari pertama kehidupan sehingga anak terlalu pendek untuk usianya (Ramayulis, dkk. 2018). Kekurangan gizi terjadi sejak bayi dalam kandungan dan pada masa awal lahir, tetapi stunting baru nampak setelah anak berusia 2 tahun. Berdampak pada tingkat kecerdasan, kerentanan terhadap penyakit, menurunkan produktifitas dan kemudian menghambat pertumbuhan ekonomi, meningkatkan kemiskinan dan ketimpangan (Kemenkeu, 2018).

Masalah kesehatan yang dialami oleh balita di dunia saat ini salah satunya adalah Stunting. Pada tahun 2017 terdapat 22,2\% atau sekitar 150,8 juta balita di dunia mengalami stunting. Lebih dari setengah balita stunting di dunia berasal dari Asia (55\%) sedangkan lebih dari sepertiganya (39\%) tinggal di Afrika. Dari 83,6 juta balita stunting di Asia, proporsi terbanyak berasal dari Asia Selatan $(58,7 \%)$ dan proporsi paling sedikit di Asia Tengah $(0,9 \%)$. Data prevalensi balita stunting yang dikumpulkan WHO (World Health Organization (2018), Kemenkes RI (2018), Indonesia termasuk ke dalam negara ketiga dengan prevalensi tertinggi di regional Asia
Tenggara/ Shouth- East Asia Regional (SEAR). Rata-rata prevalensi balita stunting di Indonesia tahun 2005-2017 adalah $36,4 \%$.

Hasil Riset Kesehatan Dasar (2018), Indonesia menunjukkan prevalensi Stunting tahun $2013(37,2 \%)$ dan tahun 2018 $(30,8 \%)$. Pada tahun 2013 prevalensi tertinggi terdapat di provinsi Nusa Tenggara Timur $(51,7 \%)$ dan prevalensi terendah di DKI Jakarta $(27,5 \%)$. Pada tahun 2018 terjadi penurunan dengan prevalensi tertinggi terdapat di provinsi Nusa Tenggara Timur $(42,6 \%)$ dan prevalensi terendah terdapat di provinsi DKI Jakarta (17,7\%). Sedangkan Provinsi Jambi prevalensi stunting $(30,1 \%)$

Berdasarkan data Dinas Kesehatan Provinsi Jambi Tahun 2018, persentase stunting tertinggi terdapat di Kabupaten Tanjung Jabung Barat (44\%) dan terendah di Kabupaten Sarolangun (18,8\%), untuk Kota Jambi angka kejadian Stunting (26.2\%).

Penyebab stunting adalah faktor gizi yang buruk yang dialami oleh ibu hamil maupun anak balita, terbatasnya layanan kesehatan termasuk layanan ante natal care, post natal care, kurangnya akses kepada makanan bergizi dan kekurangan pengetahuan ibu mengenai kesehatan dan gizi sebelum dan masa kehamilan, serta setelah ibu melahirkan (Kemendes, 2017).

Berdasarkan data Dinas Kesehatan Kota Jambi menunjukkan bahwa dari 20 Puskesmas di Kota Jambi Puskesmas Simpang Kawat merupakan Puskesmas dengan kasus terbanyak gizi kurang 36 Balita $(4,1 \%)$ dan gizi buruk 11 Balita $(1,2 \%)$ pada tahun 2018 .

Stunting dapat dicegah melalui intervensi gizi spesifik yang ditujukan dalam 1.000 hari pertama kehidupan (Ramayulis, dkk. 2018) dan pemenuhan gizi serta pelayanan kesehatan kepada ibu hamil, pemenuhan kebutuhan asupan nutrisi bagi ibu hamil, konsumsi protein pada menu harian untuk balita usia di atas 6 
bulan dengan kadar protein sesuai dengan usianya, menjaga sanitasi dan memenuhi kebutuhan air bersih serta rutin membawa buah hati untuk mengikuti posyandu minimal satu bulan sekali. Anak usia balita akan ditimbang dan diukur berat badan serta tinggi sehingga akan diketahui secara rutin apakah balita mengalami stunting atau tidak. (Kemendes RI, 2018).

Pemenuhan kecukupan gizi untuk balita, telah ditetapkan program pemberian makanan tambahan (PMT) khususnya untuk balita kurus berupa PMT lokal maupun PMT pabrikan yaitu biskuit balita. Jika berat badan telah sesuai dengan perhitungan berat badan menurut tinggi badan, maka MT (Makanan Tambahan) balita kurus dapat dihentikan dan dilanjutkan dengan makanan keluarga gizi seimbang (Kemenkes RI, 2018).

Dalam upaya mewujudkan pertumbuhan dan perkembangan anak secara optimal, khususnya pada masa balita diperlukan persiapan-persiapan baik dari orang tua terutama ibu maupun petugas kesehatan, peran perawat (petugas lapangan) sudah dimulai sejak anak dalam kandungan, yaitu dengan melakukan pemeriksaan kehamilan secara berkala dan deteksi resiko tinggi saat kehamilan kemudian menolong persalinan serta merawat bayi dan ibu pasca persalinan (Ambarwati \& Nasution, 2012). Peran perawat komunitas pada tingkatan pencegahan penyakit salah satunya adalah pencegahan primer/peningkatan kesehatan (health promotion), yaitu peningkatan status kesehatan masyarakat melalui kegiatan, diantaranya pendidikan kesehatan (health education), penyuluhan kesehatan masyarakat (PKM) seperti penyuluhan tentang gizi, perbaikan status gizi masyarakat dan pengamatan tumbuh kembang anak (growth and development monitoring) dengan cara deteksi dini (Mubarak \& Chayatin, 2009).

Upaya pencegahan stunting harus dimulai oleh ibu dari masa kehamilan terutama pada 1.000 hari pertama kehidupan, salah satunya adalah dengan pengetahuan dan sikap ibu tentang pencegahan stunting. Penguatan intervensi untuk meningkatkan pengetahuan dan sikap ibu tentang kesehatan dan gizi perlunya paket gizi (Pemberian Makanan Tambahan, Vit A. Tablet Tambah Darah) pada ibu hamil dan balita, memahami pengasuhan dan pembinaan tumbuh kembang anak (Kemenkeu, 2018).

Hasil penelitian Ramdaniati (2018) tentang Hubungan Tingkat Pendidikan, Tingkat Pengetahuan dan Sikap Ibu Tentang Gizi Terhadap Kejadian Stunting Pada Anak Usia 6-59 Bulan di Desa Paerang, Kecamatan Mekarjaya Kabupaten Pandeglang Tahun 2018, hasil penelitian ini menunjukkan dari 41 responden, hasil analisis bivariat antara tingkat pendidikan dengan kejadian stunting menunjukkan bahwa nilai $P$ value $>0,05$ yaitu 1,000 sehingga dapat disimpulkan bahwa tidak ada hubungan yang bermakna antara tingkat pengetahuan responden dengan kejadian stunting pada anak usia 6-59 bulan di Desa Pareang. Hasil analisis bivariat antara tingkat pengetahuan dengan kejadian stunting menunjukkan bahwa nilai $\mathrm{P}$ value $>0,05$ yaitu 0,304 sehingga dapat disimpulkan bahwa tidak ada hubungan antara tingkat pengetahuan responden tentang gizi dengan kejadian stunting pada anak usia 6-59 bulan di Desa Pareang.

\section{METODE PENELITIAN}

Penelitian ini merupakan penelitian kuantitatif dengan menggunakan desain cross sectional. Peneliti akan melihat hubungan variabel pengetahuan dengan sikap ibu dengan upaya pencegahan stunting pada balita. Penelitian ini dilaksanakan pada tanggal 24 juni-8 juli 2019 di Wilayah Kerja Puskesmas Simpang Kawat Kota Jambi. Populasi dalam penelitian ini adalah seluruh ibu yang memiliki balita sebanyak 881 orang dengan jumlah sampel sebanyak 87 orang, teknik 
pengambilan sampel secara Proporsional Random Sampling yang memenuhi kriteria inklusi.

\section{HASIL DAN PEMBAHASAN}

A. Karakteristik Ibu dan Balita

1.1 Karakteristik Ibu

a. Karakteristik Ibu Berdasarkan

Pendidikan

Tabel 1 Karakteristik Ibu Berdasarkan Pendidikan di Wilayah Kerja Puskesmas Simpang Kawat Kota Jambi Tahun 2019

\begin{tabular}{llcc}
\hline No. & Pendidikan & $\mathrm{f}$ & $(\%)$ \\
\hline 1. & SD & 0 & 0 \\
2. & SMP & 13 & 14.9 \\
3. & SMA & 54 & 62 \\
4. & Diploma & 13 & 14.9 \\
5. & Sarjana & 7 & 8 \\
\hline & Total & 87 & 100 \\
\hline
\end{tabular}

Berdasarkan tabel 4.1 diatas

didapatkan hasil bahwa frekuensi ibu yang memiliki balita berdasarkan pendidikan sebagian besar ibu $62 \%$ berpendidikan menengah keatas.

b. Karakteristik Ibu Berdasarkan Pekerjaan

Tabel 2 Karakteristik Ibu Berdasarkan Pekerjaan di Wilayah Kerja Puskesmas Simpang Kawat Kota Jambi Tahun 2019

\begin{tabular}{llcc}
\hline No & \multicolumn{1}{c}{ Pekerjaan } & f & $(\%)$ \\
\hline 1. & Belum Bekerja & 0 & 0 \\
2. & IRT & 57 & 65.5 \\
3. & Mahasiswa & 0 & 0 \\
4. & Petani & 0 & 0 \\
5. & PNS & 0 & 0 \\
6. & Wiraswasta & 7 & 8 \\
7. & Pegawai Swasta & 23 & 26.4 \\
\hline \multicolumn{2}{l}{ Total } & 87 & 100 \\
\hline & Berdasarkan tabel & 42 & diatas
\end{tabular}

didapatkan hasil bahwa frekuensi ibu yang memiliki balita berdasarkan pekerjaan sebagian besar Ibu $65.5 \%$ bekerja sebagai IRT.

\subsection{Karakteristik Balita}

Berdasarkan tabel 3 didapatkan hasil bahwa frekuensi karakteristik balita menurut Depkes RI (2018), TB/Usia 0-59 bulan di Wilayah Kerja Puskesmas
Simpang Kawat Kota Jambi masih dalam kategori normal.

Tabel 3 Karakteristik Balita Berdasarkan TB/Usia di Wilayah Kerja Puskesmas Simpang Kawat Kota Jambi Tahun 2019

\begin{tabular}{|c|c|c|}
\hline No. & TB (cm) / Usia (bulan) & $\mathrm{n}$ \\
\hline 1. & $\begin{array}{l}68.9-80.5 \mathrm{~cm} \mathrm{/} 0-12 \\
\text { bulan }\end{array}$ & 12 \\
\hline 2. & $\begin{array}{l}80-92.9 \mathrm{~cm} \mathrm{/} 13-24 \\
\text { bulan }\end{array}$ & 20 \\
\hline 3. & $\begin{array}{l}87.4-93.9 \mathrm{~cm} / 25-36 \\
\text { bulan }\end{array}$ & 22 \\
\hline 4. & $\begin{array}{l}94.1-111.7 \mathrm{~cm} / 37-48 \\
\text { bulan }\end{array}$ & 24 \\
\hline 5. & $\begin{array}{l}99.9-119.2 \mathrm{~cm} / 49-59 \\
\text { bulan }\end{array}$ & 18 \\
\hline & Total & 87 \\
\hline
\end{tabular}

Sedangkan definisi Stunting (kerdil) adalah kondisi dimana balita memiliki panjang dan tinggi badan yang kurang jika dibandingkan dengan umur. Kondisi ini diukur dengan panjang atau tinggi badan yang lebih dari minus dua standar deviasi median standar pertumbuhan anak dari WHO (Kemenkes RI, 2018).

\section{B. Analisa Univariat}

\section{Gambaran Pengetahuan}

Tabel 4 Distribusi Frekuensi Pengetahuan Ibu Tentang Upaya Pencegahan Stunting Pada Balita di Wilayah Kerja Puskesmas Simpang Kawat Kota Jambi Tahun 2019

\begin{tabular}{cccc}
\hline \multirow{2}{*}{ No } & Pengetahuan & \multicolumn{2}{c}{ Jumlah } \\
\cline { 3 - 4 } & & $\mathrm{f}$ & $\%$ \\
\hline 1 & Tinggi & 57 & 65.5 \\
2 & Rendah & 30 & 34.5 \\
\hline & Total & 87 & 100 \\
\hline
\end{tabular}

Berdasarkan tabel 4 diatas diketahui gambaran pengetahuan ibu di Wilayah Kerja Puskesmas Simpang Kawat Kota Jambi Tahun 2019, sebagian besar Ibu $65.5 \%$ memiliki pengetahuan tinggi tentang upaya pencegahan stunting. 


\section{Gambaran Sikap Ibu}

Tabel 5 Distribusi Frekuensi Sikap Ibu Tentang Upaya Pencegahan Stunting Pada Balita di Wilayah Kerja Puskesmas Simpang Kawat Kota Jambi Tahun 2019

\begin{tabular}{llcc}
\hline \multirow{2}{*}{ No } & \multirow{2}{*}{ Sikap } & \multicolumn{2}{c}{ Jumlah } \\
\cline { 3 - 4 } & & $\mathrm{f}$ & $\%$ \\
\hline 1 & Baik & 56 & 64.4 \\
2 & Kurang Baik & 31 & 35.6 \\
\hline & Total & 87 & 100 \\
\hline
\end{tabular}

Berdasarkan tabel 4.5 diatas dapat diketahui gambaran sikap Ibu di di Wilayah Kerja Puskesmas Simpang Kawat Kota Jambi Tahun 2019, sebagian besar Ibu (64.4\%) memiliki sikap baik tentang upaya pencegahan stunting.

\section{Gambaran Upaya Pencegah}

Tabel 6 Distribusi Frekuensi Upaya Pencegahan Stunting Pada Balita di Wilayah Kerja Puskesmas Simpang Kawat Kota Jambi Tahun 2019

\begin{tabular}{lcc}
\hline Upaya Pencegahan & \multicolumn{2}{c}{ Jumlah } \\
\cline { 2 - 3 } & $\mathrm{f}$ & $\%$ \\
\hline Baik & 59 & 67.8 \\
Kurang Baik & 28 & 32.2 \\
\hline \multicolumn{1}{c}{ Total } & 87 & 100 \\
\hline
\end{tabular}

Berdasarkan tabel 6 diatas dapat diketahui gambaran upaya pencegahan stunting pada balita di Wilayah Kerja Puskesmas Simpang Kawat Kota Jambi Tahun 2019, sebagian besar Ibu (67.8\%) memiliki upaya pencegahan stunting yang baik.

Tabel 7 Hubungan Pengetahuan Dengan Upaya Pencegahan Stunting Pada Balita di Wilayah Kerja Puskesmas Simpang Kawat Kota Jambi Tahun 2019

\begin{tabular}{lccccccc}
\hline $\begin{array}{l}\text { Pengeta- } \\
\text { huan }\end{array}$ & \multicolumn{6}{c}{ Upaya Pencegahan } & \multicolumn{2}{l}{ Jumlah } & $p$ \\
\cline { 2 - 7 } & \multicolumn{2}{c}{ Baik } & \multicolumn{2}{c}{ Kurang } & & & \\
\cline { 2 - 7 } & $\mathrm{n}$ & $\%$ & $\mathrm{n}$ & $\%$ & $\mathrm{n}$ & $\%$ & \\
\hline Tinggi & 41 & 71.9 & 16 & 28.1 & 57 & 100 & 0.37 \\
Rendah & 18 & 60 & 12 & 40 & 30 & 100 & \\
\hline \multicolumn{1}{c}{ Total } & 59 & 67.8 & 28 & 32.2 & 87 & 100 & \\
\hline
\end{tabular}

Berdasarkan tabel 7 tentang hubungan pengetahuan ibu dengan upaya pencegahan stunting pada balita di Wilayah Kerja Puskesmas Simpang Kawat Kota Jambi didapatkan dari 57 Ibu yang memiliki pengetahuan tinggi, sebagian besar Ibu (71.9\%) mempunyai upaya pencegahan stunting baik terhadap upaya pencegahan stunting. Hasil uji statistik dapat diketahui p-value $0.373(p>0,05)$ maka dapat disimpukan tidak ada hubungan yang bermakna/ signifikan antara pengetahuan dengan upaya pencegahan stunting pada balita di wilayah kerja Puskesmas Simpang Kawat Kota Jambi.

Hasil penelitian ini sejalan dengan penelitian penelitian Ramdaniati (2018) tentang Hubungan Tingkat Pendidikan, Tingkat Pengetahuan dan Sikap Ibu Tentang Gizi Terhadap Kejadian Stunting Pada Anak Usia 6-59 Bulan di Desa Paerang, Kecamatan Mekarjaya Kabupaten Pandeglang Tahun 2018, didapatkan Ibu yang berpengetahuan tinggi 9 Ibu $(60 \%)$ sedangkan Ibu yang berpengetahuan rendah 6 Ibu (40\%) dan Ibu yang bersikap positif 7 Ibu $(46,7 \%)$ sedangkan Ibu yang bersikap negatif 8 Ibu $(53,3 \%)$.

Pengetahuan merupakan salah satu faktor yang sangat penting untuk terbentuknya tindakan seseorang. Pengetahuan yang didasarkan dengan pemahaman akan menumbuhkan sikap positif dalam upaya pencegahan stunting dengan dilakukannya kerja sama tim kesehatan dilakukan melalui intervensi gizi spesifik untuk mengatasi permasalahan gizi anak usia 0-23 bulan dengan pemberian konseling gizi kepada individu dan keluarga dapat membantu untuk mengenali masalah kesehatan gizi terkait, memahami penyebab terjadinya masalah gizi, dan membantu individu serta keluarga memecahkan masalahnya sehingga terjadi perubahan perilaku untuk dapat menerapkan perubahan perilaku Ramayulis, dkk. (2018).

Hasil analisis penelitian didapatkan sebagian besar (71.9\%) Ibu berpengetahuan tinggi memiliki upaya pencegahan baik. Jika Ibu memiliki pengetahuan tinggi 
tentang pengertian, gejala, akibat terjadinya stuning, dan pencegahan pada 1.000 Hari Pertama Kehidupan (HPK), maka semakin baik pula pengetahuan tentang upaya pencegahan stunting.

Peran perawat komunitas dalam melakukan upaya pencegahan stunting dapat dilakukan melalui pencegahan primer

Tabel 8 Hubungan Sikap Ibu Tentang Upaya Pencegahan Stunting Pada Balita di Wilayah Kerja Puskesmas Simpang Kawat Kota Jambi Tahun 2019

\begin{tabular}{|c|c|c|c|c|c|c|c|}
\hline \multirow[t]{3}{*}{ Sikap } & \multicolumn{4}{|c|}{ Upaya Pencegahan } & \multicolumn{2}{|c|}{ Jumlah } & \multirow[t]{2}{*}{ p-value } \\
\hline & \multicolumn{2}{|c|}{ Baik } & \multicolumn{2}{|c|}{ Kurang Baik } & & & \\
\hline & $\mathrm{n}$ & $\%$ & $\mathrm{n}$ & $\%$ & $\mathrm{n}$ & $\%$ & \\
\hline Baik & 43 & 76.8 & 13 & 23.2 & 56 & 100 & 0.030 \\
\hline Kurang Baik & 16 & 51.6 & 15 & 48.4 & 31 & 100 & \\
\hline Total & 59 & 67.8 & 28 & 32.2 & 87 & 100 & \\
\hline
\end{tabular}

Berdasarkan tabel 8 diatas tentang hubungan sikap ibu dengan upaya pencegahan stunting pada balita di Wilayah Kerja Puskesmas Simpang Kawat Kota Jambi didapatkan bahwa dari 56 Ibu yang memiliki sikap baik sebagian besar Ibu (76.8\%) mempunyai upaya pencegahan baik terhadap upaya pencegahan stunting. Hasil uji statistik didapatkan $p$-value 0.030 $(p<0,05)$ maka dapat disimpulkan bahwa ada hubungan yang bermakna/ signifikan antara sikap Ibu dengan upaya pencegahan stunting pada balita di Wilayah Kerja Puskesmas Simpang Kawat Kota Jambi.

Hasil penellitian ini sejalan dengan penelitian Olsa, Edwin, dkk (2017). Hubungan sikap dan pengetahuan Ibu terhadap kejadian stunting pada anak baru masuk sekolah dasar di Kecamatan Nanggalo, hasil penelitian menunjukkan bahwa sikap ibu sebagian besar pada kategori yang positif sebesar $55.2 \%$, sedangkan sikap ibu dengan kategori yang negatif sebesar $44.8 \%$. Hasil penelitian menunjukkan bahwa pengetahuan ibu yang cukup $48.7 \%$. Hasil statistik dengan menggunakan chi-square antara sikap ibu dengan kejadian stunting diperoleh nilai $\mathrm{p}<5$ (0.00), maka terdapat hubungan yang bermakna antara sikap ibu dengan kejadian stunting pada anak baru masuk sekolah dasar di Kecamatan Nanggalo. (primary preveention) dengan peningkatan kesehatan (health promotion) yaitu peningkatan status kesehatan masyarakat dengan memberikan penyuluhan kesehatan masyarakat berupa penyuluhan tentang gizi dan pengamatan tumbuh dan kembang balita.
Hal ini disesuaikan dengan teori yang dikemukakan Lawrence Green (1980) dalam Notoatmodjo (2014) bahwa perilaku kesehatan dipengaruhi oleh 3 faktor yaitu faktor predisposisi (predisposing factors) yang terwujud dalam pengetahuan, sikap, kepercayaan, keyakinan, nilai-nilai dan sebagainya, faktor pendukung (enabling factors) yang terwujud dalam lingkungan fisik, tersedia atau tidak tersedianya fasilitas-fasilitas atau sarana-sarana kesehatan, misalnya puskesmas, obatobatan, jamban dan sebagainya, dan faktor pendorong (reinforcing factors) yang terwujud dalam sikap dan perilaku petugas kesehatan atau petugas lain yang merupakan kelompok referensi dari perilaku masyarakat. Sikap ibu termasuk dalam pemberian makanan pada anak penting dalam pencehagan stunting. Menurut Angriani dkk, 2019 Ibu yang mempunyai sikap positif, memberikan ASI Eksklusif dan ASI sampai usia 2 tahun, dapat mencegah stunting pada anak.

Hasil analisis penelitian didapatkan sebagian besar (76.8\%) Ibu yang mempunyai sikap baik memiliki upaya pencegahan. Upaya pencegahan stunting tidak hanya dilakukan oleh Ibu tetapi juga harus didukung oleh tenaga kesehatan.

Upaya pencegahan stunting yang dapat dilakukan oleh tenaga kesehatan yaitu 
pencegahan spesifik (spesific protection) dan pencegahan sekunder (secondary prevention) dengan melakukan deteksi dini untuk melihat penemuan stunting. Serta memberikan pemahaman tentang stunting sehingga terjadi perubahan sikap yang diharapkan dalam mencapai tingkat kesehatan yang optimal.

Berdasarkan hasil penelitian dapat diartikan bahwa pengetahuan yang tinggi didukung dengan sikap yang baik akan tercermin perilaku positif. Sehingga dapat diartikan pengetahuan tinggi dengan sikap yang baik dapat diwujudkan dalam upaya pencegahan yang baik.

\section{SIMPULAN}

Berdasarkan hasil penelitian yang dilakukan pada 87 ibu yang memiliki balita di Wilayah Kerja Puskesmas Simpang Kawat Kota Jambi Tahun 2019 diperoleh kesimpulan : Sebagian besar Ibu $(67.8 \%)$ memiliki upaya pencegahan stunting yang baik, sebagian besar Ibu (65.5\%) memiliki pengetahuan tinggi terhadap upaya pencegahan stunting, sebagian besar Ibu (64.4\%) memiliki sikap baik terhadap upaya pencegahan stunting. Tidak ada hubungan yang bermakna antara pengetahuan dengan upaya pencegahan stunting pada balita dimana $p$-value $=0.373$ $(\mathrm{p}>0.05)$. Ada hubungan yang bermakna antara sikap dengan upaya pencegahan stunting pada balita dimana $p$-value $=0.030$ $(\mathrm{p}<0.05)$.

Diperlukan pembinaan peningkatan gizi guna untuk penyehatan balita tentang pencegahan stunting di Provinsi dan Kota Jambi, serta dapat memberikan penyuluhan untuk masyarakat sehingga menurunnya angka kejadian stunting di provinsi Jambi.

\section{DAFTAR PUSTAKA}

Ambarwati, Respati dan Nasution, Nita. 2012. Asuhan Keperawatan Bayi \& Balita. Yogyakarta: Cakrawala Ilmu Angriani S, Merita, Aisah. 2019. Hubungan Lama Pemberian Asi dan Berat Lahir dengan Kejadian Stunting pada Balita di Wilayah Kerja Puskesmas Siulak Mukai Kabupaten Kerinci Tahun 2019. Jurnal Akademika Baiturrahim. 8(2) : 244-251.

Azwar, Saifuddin. 2016. Sikap Manusia dan Teori Pengukurannya. Yogyakarta: Pustaka Pelajar

Hanggraeni, D. 2011. Perilaku Organisasi. Jakarta: Lembaga penerbit Fakultas Ekonomi UI. https://www.google.com/url?sa=t\&so urce=web\&rct=j\&url=http://www.dep kes.go.id/download.php\%3Ffile\%3D download/pusdatin/buletin/BuletinStunting2018.pdf\&ved=2ahUKEwiJxNzmvji AhWM63MBHV3dD3sQFjAAegQI ARAB\&usg=AOvVaw2Sdwa9UKB6 irtTY7JRuJCn

Kalla, J. 2017. 100 Kabupaten/Kota Prioritas Untuk Intervensi Anak Kerdil (Stunting). Jakarta: Tim Nasional Percepatan Penanggulangan Kemiskinan.https://www.google.com/ url?sa=t\& source $=$ web\&rct $=$ j\&url=htt p://www.tnp2k.go.id/images/uploads/ downloads/Binder_Volume1.pdf\&ve d=2ahUKEwipjf_WmfjjAhW0heYK HY5bBX4QFjAAegQIBRAC\&usg= AOvVaw2u7lyKEbqYGDEQIbeIlbqi

Kartika, Iin . 2017. Buku Ajar Dasar-Dasar Riset Keperawatan dan Pengolahan Data Statistik. Jakarta. Trans Info Media

Kemendes. 2017. Buku Saku Desa dalam Penanganan Stunting. Jakarta: Kementrian Desa, Pembangunan Daerah Tertinggal dan Transmigrasi. https://www.google.com/url?sa=t\&so urce=web\&rct=j\&url=http://siha.depk es.go.id/portal/files_upload/Buku_Sa ku_Stunting_Desa.pdf\&ved=2ahUKE wjUzdzFmvijAhU6ILcAHaALAiMQ FjAAegQIAhAB\&usg=AOvVaw0Zh QjDzzZBIkN4vZimiJSI

Kemenkes RI. 2018. Cegah Stunting Itu Penting. Jakarta: Warta Kesmas. 
https://www.google.com/url?sa=t\&so urce=web\&rct=j\&url=http://www.kes mas.kemkes.go.id/assets/upload/dir_5 19d41d8cd98f00/files/Warta-KesmasEdisi-

022018_1136.pdf\&ved=2ahUKEwjD zZimvjiAhWB7HMBHULTDvIQFjA AegQIARAB\&usg=AOvVaw29oOM 6JZCQdUxhZfOKbi-X

Kemenkeu. 2018. Penanganan Stunting Terpadu Tahun 2018. Direktur Anggaran Bidang Pembangunan Manusia dan Kebudayaan. https://www.google.com/url?sa=t\&so urce=web\&rct=j\&url=http://siha.depk es.go.id/portal/files_upload/Buku_Sa ku_Stunting_Desa.pdf\&ved=2ahUKE wi7yNDAm_jjAhXbbSsKHVQRC9I QFjAAegQIAxAB\&usg=AOvVaw0Z $\underline{\text { hQjDzzZBIkN4vZimiJSI\&cshid }=156}$ 5437126225

Kementerian Kesehatan RI. 2018. Situasi Balita Pendek (Stunting) di Indonesia. Jakarta: Buletin Jendela Data dan Informasi.

Mubarak, Iqbal dan Chayatin, Nurul. 2009. Ilmu Keperawatan Komunitas Pengantar dan Teori. Buku 1. Jakarta: Salemba Medika

Notoatmodjo, Soekidjo. 2014. Promosi Kesehatan dan Perilaku Kesehatan. Jakarta: Rineka Cipta

Notoatmodjo. 2018. Metodologi Penelitian Kesehatan. Jakarta: Rineka Cipta

Nurarif, Amin dan Kusuma, Hardhi. 2015. Asuhan Keperawatan Berdasarkan Diagnosa Medis \& NANDA NIC NOC. Yogyakarta: Mediaction Publishing Jogjakarta

Olsa, Edwin, dkk (2017). Hubungan Sikap dan Pengetahuan Ibu Terhadap Kejadian Stunting Pada Anak Baru Masuk Sekolah Dasar di Kecamatan Nanggalo.

http://jurnal.fk.unand.ac.id/index.php/ $\mathrm{jka} /$ article/view/733/589
Priyoto. 2014. Teori Sikap dan Perilaku dalam Kesehatan Dilengkapi Contoh Kuesioner. Yogyakarta: Nuha Medika

Ramayulis, dkk. 2018. Stop Stunting dengan Konseling Gizi. Jakarta: Penerbit Plus+

Ramdaniati. 2018. Hubungan Tingkat Pendidikan, Tingkat Pengetahuan dan Sikap Ibu Tentang Gizi Terhadap Kejadian Stunting Pada Anak Usia 659 Bulan di Desa Paerang, Kecamatan Mekarjaya Kabupaten Pandeglang

Tahun2018.http://www.drdbanten.org /jurnal/index.php/jurnal/article/view/4 1 Diakses tanggal 29 Maret 2019

Riskesdas. 2018. Riset Kesehatan Dasar. Kementrian Kesehatan RI, Jakarta

Rukmana, dkk. 2016. Faktor Risiko Stunting Pada Anak Usia 6-24 Bulan di Kota Bogor. Diakses tanggal 31 Maret 2019.

Salman, dkk. 2017. Hubungan Pengetahuan Gizi Ibu Dengan Kejadian Stunting Pada Anak Balita di Desa Buhu Kecamatan Talaga Jaya Kabupaten Gorojntalo.http://www.jurnal.poltekk esgorontalo.ac.id/index.php/JHN/artic le/view/119 Diakses tanggal 31 Maret 2019.

STIKBA. 2015. Panduan Penulisan Skripsi dan Karya Tulis Ilmiah. Sekolah Tinggi Ilmu Kesehatan Baiturrahim Jambi

Sujarweni, Wiratna. 2014. Metodologi Penelitian Keperawatan. Yogyakarta : Gava Media

Sulistyoningsih. 2011. Gizi Untuk Kesehatan Ibu dan Anak. Yogyakarta: Graha Ilmu

Supardi, Sudibyo \& Rustika. 2013. Metodologi Riset Keperawatan. Jakarta: Trans Info Media

Suparmi, dkk. 2018. Buku Saku Bayi dan Balita Sehat. Jakarta: Trans Info Media 
Susilowati dan Kuspriyanto. 2016. Gizi Dalam Daur Kehidupan. Bandung: PT Rafika Adimata

Wawan, A dan Dewi, M. 2011. Teori dan Pengukuran Pengetahuan, Sikap dan Perilaku Manusia. Yogyakarta: Nuha Medika 